\title{
Evaluation of Placental Epigenetic Changes due to Morphine Consumption
}

\author{
Evaluación de Cambios Epigenéticos de la Placenta por Consumo de Morfina
}

\author{
Masoomeh Kazemi*; Elaheh Tekieh*; Sahar Golabi** \& Hedayat Sahraei*
}

KAZEMI, M.; TEKIEH, E.; GOLABI, S. \& SAHRAEI, H. Evaluation of placental epigenetic changes due to morphine consumption. Int. J. Morphol., 34(1):252-261, 2016.

SUMMARY: Based on previous studies, a variety of bioenvironmental elements including inappropriate nutrition, diseases, infections, stressors, and medications are involved in epigenetic changes. Drug abuse is one of the most important causes of epigenetic changes and a concern in today's world. Studies have shown that morphine use by pregnant mothers causes several disorders in mothers in addition to transferring abnormalities to the next generation (placenta and embryo). Epigenetic factors such as morphine cause changes in gene expression in placenta as the first embryonic defense barrier. Because placenta does all the nutritional exchanges between mother's and embryo's blood, placental health guarantees normal embryonic development. Many studies have been conducted on defects caused by epigenetic factors including medication use. Opioid abuse including morphine abuse has endangered health of many people. Morphine changes gene expression by binding to opioid receptors on placental villi. Based on the studies, major epigenetic changes due to drug use are mediated by DNA methylation and histone changes. Recognizing different epigenetic factors and their effect on placental and embryonic development is among modern studies. The importance of recognizing epigenetic changes caused by drug abuse by pregnant mothers can be the most important way to prevent adulthood diseases in the embryo and in some cases miscarriage. Changes induced by epigenetic factors can be moderated or reversed by controlling the epigenetic factors. This study is a review of changes caused by morphine use by pregnant rats on development of placenta.

KEY WORDS: Development; Morphine; Embryo; Epigenetic; Pregnancy; Placenta.

\section{INTRODUCTION}

Today, drug consumption is one of the main factors influencing epigenetic. Abuse of different opiates is on the rise; the most significant threat to health and the family is dependency to these drugs (Ornoy et al., 1996). Opiates consumers include pregnant mothers, and the effects of these drugs not only affect the mother, but also transmit to the next generation (Nettleton et al., 2008; Ornoy et al.). Epigenetic changes can be caused by various environmental elements such as social-psychic stresses, diet, infections, drugs, structural heredity, and gene location in chromosomal width. Research into the causes of epigenetic changes is very important because epigenetic affects the quality of life and can transmit to the next generation via inheritance (Godfrey et al., 2007; Li et al., 2007). Epigenetic factors including drug consumption, unsuitable nutrition, and horrible bioenvironmental situations, can cause epigenetic changes in embryos and placenta. Principal epigenetic changes are relevant to external factors (Chelbi \& Vaiman, 2008;
Gluckman et al., 2008; Novakovic \& Saffery, 2012). In mammals, DNA methylation and histone variations are the most prevalent epigenetic changes (Cedar \& Bergman, 2009; Chelbi \& Vaiman). Based on studies on growth and development of embryo and placenta, imprinting tribulations can increase embryonic defects during pregnancy, and this phenomenon reveals that methylation changes are also effective in genesis processes before implantation and dependent on epigenetic factors such as drug consumption (Chelbi \& Vaiman; DeChiara et al., 1991). Opiates consumption causes disruptions in the normal development of placenta and embryo, especially in the initial stages of pregnancy (James et al., 2004; Kazemi et al., 2010). Many other epigenetic factors may cause different tribulations of pregnancy, but these are simpler to remain unrecognized. Two potential brakes of growth and development that are from placental epigenetic malformations are intrauterine growth restriction.

\footnotetext{
* Neuroscience Research Center, Baqiyatallah University of Medical Sciences, Tehran, Iran.

** Department of Physiology, ShahidBeheshti University of Medical Sciences, Tehran, Iran.
} 


\section{IURL and preeclampsia}

These two undesirable outcomes of pregnancy originate from the placenta. Epigenetic factors can promote the abnormal formation of the placenta, resulting in placental preeclampsia and IURL. Research shows that preeclampsia and a malformed placenta can prevent creation of the embryo (Amiel et al., 2002; Grati et al., 2005). The passage of drugs into the placenta is dependent on a range of factors. Fat soluble compounds pass into the placenta easily. However, water soluble substances have less passage into the placenta because of the heavier molecular weight. Drug incorporation into plasma proteins affects the free drug content that can pass into the placenta. Indeed, all drugs except organic ions such as heparin and insulin can pass into the placenta to some degree. In regards to tissue pathology, the passage of morphine across the placental barrier has multiple effects on the embryo (Behravan \& Piquette-Miller, 2007; DiPirro \& Kristal, 2004; Fowden et al., 2006). Opiates such as morphine act on opioid receptors (mu, kappa and delta), especially mu receptors. Opiate receptors are present on placental villi and contribute to the genesis of placental cells and their function. Majority of mu receptors are on the endothelial membrane of erythrocytes (Trescot et al., 2008; Corpening et al., 2000; Seward et al., 1991). For this reason, malformations that result from edible morphine consumption by pregnant mothers have maximal impact on the placental blood network especially the embryonic portion (Kazemi et al., 2010a, 2010b). In addition, morphine transmission across the placental barrier causes malformations in embryonic nervous system development including choroid plexus, brain ventricles, and the visual system (Kazemi et al., 2011a, 2011b, 2012a, 2012b; Sahraei et al., 2013). Recognition and understanding of the epigenetic changes that occur on the embryo and placenta as a result of opiates consumption can be a path to prevention before treatment. It is important because more embryos of opiate addicted mothers are susceptible to various cardiovascular disorders, type 2 diabetes, excessive weight, and schizophrenia. The placenta performs vital functions such as nutrient transport between the circulatory systems of the mother and embryo during intra-uterus growth and development. Normal genesis of the embryo is reliant on constant interactions between transcriptional factors, epigenetic and environmental factors (Esteller \& Herman, 2002; Grayson et al., 2005; Maltepe et al., 2005; Simmons et al., 2001). Morphine is a meddlesome factor in normal embryonic development, and the mother's dependency to opiates is a growing concern because of various epigenetic factors including stress. Addiction is a universal problem that curtails the health of mothers and the developing embryos (Maltepe et al., 2010; Maccani \& Marsit, 2009; Renthal \& Nestler, 2008). In regards to this point, the placenta is an initial barrier for the embryo against morphine. In this review article we survey the effects of edible morphine consumption by pregnant mothers and the epigenetic changes that occur in the placenta. For better descriptions of malformations that result from morphine consumption and tissue morphological changes of the placenta, tissue images from published articles were used.

\section{Opioids-morphine.}

Opioids have been used for thousands of years for the treatment of pain (Trescot et al.). In 1973, a graduate student, Candace Pert, used radioactive morphine to evaluate the locations of the site of action of morphine. Evidence for the existence of multiple opioid receptor subtypes arose from work identifying the different anatomical location and pharmacological profiles of compounds that were eventually used to name them, i.e., morphine (mu), ketocyclazocine (kappa) and vas deferens (delta). Cellular mechanisms of action opioid receptors, G-protein- coupled receptors, such as those for opioids, have no direct link with effector proteins; instead the message is relayed via a G protein (Trescot $e t$ al.; Seward et al.).

\section{Morphine and its derivatives are used today for the treatment of acute and chronic pain.}

It is now understood that morphine and other opioid drugs act on an endogenous opioidergic system, which is not only involved in setting pain (nociceptive) threshold and controlling nociceptive processing, but also participates in modulation of gastrointestinal, endocrine and autonomic function, as well as a possible role in cognition (Trescot $e t$ al.; McDonald \& Lambert, 2005). Morphine, a narcotic, directly affects the central nervous system. Besides relieving pain, Morphine impairs mental and physical performance, relieves fear and anxiety, and produces euphoria; morphine's euphoric effects can be highly addictive. Tolerance and physical and psychological dependence develop quickly.

The nonalkalized form of morphine crosses the blood brain barrier easier and alkalization of the blood increases the fraction of non-ionized morphine (Trescot et al.; McDonald \& Lambert).

\section{Epigenetic, DNA methylation.}

Epigenetics is most commonly defined as the study of alterations in gene function that are heritable through both mitosis and meiosis, but do not involve any change in the DNA sequence itself (Esteller \& Herman; Renthal \& Nestler). At a molecular level, epigenetic mechanisms comprise first and foremost chemical modifications of the DNA and histone proteins, the major constituents of the 
chromatin. These modifications primarily involve acetylation, methylation, phosphorylation, ubiquitination, and sumoylation (Renthal \& Nestler; Reik, 2007).

DNA methylation most commonly occurs at cytosine-guanine dinucleotides $(\mathrm{CpG})$, and is generally associated with transcriptional silencing. Silencing takes place through direct inhibition of the binding of transcription factors, or the indirect recruitment of methyl-CpG binding proteins (MBPs) and associated repressive chromatinremodeling activity. The addition of amethyl group from SAM (S-adenosyl-L-methionine) substrates to the cytosine is catalyzed by DNA (cytosine-5)-methyltransferases (Fowden \& Forhead, 2004; Godfrey et al.). Histone methylation on lysine is associated with both actively transcribed and silenced genes depending on the residue. It can occuras mono, diortrimethylation, which modulates gene expression differently. Histone methylation is also found on arginine $(\mathrm{R})$ in both mono- and di-methylated forms, but the impact on chromatin structure is not well understood (Cedar \& Bergman; Li et al.). The nucleosome is a protein complex that forms an important constituent of chromatin together with genomic DNA, named as the nucleosomes that consists of two copies of each of the four core histones (H2A, H2B, $\mathrm{H} 3$ and $\mathrm{H} 4$ ), and is swabbed by the DNA. Modifications of histones refer to the covalent modifications of the aminoterminal tails and the core of nucleosomal histones. The histone modifications, including acetylation, methylation, phosphorylation, ADP ribosylation, and ubiquitylation, are different types of histone modifications. They can extend the information content of the underlying DNA sequence and confer unique transcriptional potential (Cedar \& Bergman; Delaval \& Feil, 2004).

\section{Changes that result from morphine as an epigenetic fac- tor on syncytotrophoblast and cytotrophoblast cells of the pregnant rat's placenta.}

At the beginning of implantation, trophoblastic cells of the blastocyst in the placental pole penetrate mucosal cells of the uterus. Epithelial stem cells (trophoblastic cells) differentiate in the placenta (Fowden et al., 2006, 2008). The role of epigenetic factors in the regulation of placental growth and development starts before implantation. Epigenetic factors such as DNA methylation, histone alternations and nontranscriptional RNAs, are effective in driving gene expression patterns, and these changes have a pivotal role in the genesis of the embryo and placenta (Maltepe et al., 2010; Maccani \& Marsit). Organism development from a singleegg to adulthood includes a set of pre-programmed and differentiation processes. Trophoblastic cells of embryo and placenta differentiate from egg cell (Fowden et al., 2006; Reik). Epigenetic factors cause changes in gene expression that are necessary for the normal process of trophoblastic cell development; moreover, they cause changes in numerous transcription factors. Normally, trophoblastic cells differentiate to inner mass (embryonic) and placental cells. In this situation, we have a decrease in placental cell methylation compared with inner mass cells (Godfrey, 2002; Reik). A second wave of epigenetic reprogramming happens in primordial germ cells (PGCS). These cells are produced by the inner cell mass and migrate to extra-embryonic mesoderm of the growing embryo. After zygosis, in the primary stage of differentiation, genome methylation levels in PGCS decrease dramatically (Hajkova et al., 2002; Reik). These data have resulted in the discovery of some imprinted genes such as insulin growth factor 2 receptor in the rat that drive expression of paternal genes (e.g., paternally expressed gene, PGE). Igf2 growth factor gene is important in the placenta and embryo growth balance. For example, Igf2 causes an increase in the normal expression of paternal genes. In addition, the abnormal expression can disrupt the normal growth of rat embryo (Cui et al., 2003; Godfrey). Opiates consumption increases methylation changes in trophoblastic cells. Trophoblastic cell differentiation to embryonic mass and placenta is influenced by epigenetic factors (Rozisky et al., 2012; Russ et al., 2000). Malnutrition causes an increase in the mother's blood sugar (even temporary) and may affect gene transcription of embryo and mother communicating trophoblastic cells; in this way, insulin cannot pass into the placenta but excess glucose into the placenta can increase the infant's blood sugar (Aronow et al., 2001; DeChiara et al.; Maltepe et al., 2010). The total amount of DNA methylation changes in opiate dependency differs between embryo and extra-embryo. Placental trophoblastic cells show hypomethylation, and embryonic mass trophoblastic cells demonstrate hyper-methylation (Behravan \& Piquette-Miller; Gluckman \& Hanson, 2000). Trophoblastic cells differentiate into two layers and the placenta develops from this part. An inner layer, named the cytotrophoblast, includes cells that are mononuclear and have cellular cleavage potency. The outer layer consists of syncytotrophoblast cells that are polynuclear and do not have any distinct membrane bound (Aronow et al.; Goswami et al., 2006; Russ et al., 2000). Studies show that edible morphine consumption by pregnant mothers cause a disorder in the genesis and proliferation of cytotrophoblastic and syncytiotrophoblastic cells. Maximum morphine effects include the inhibition of differentiation in cells that have proliferation capacity. In this regard, morphine causes abnormal division of cytotrophoblastic cells (Aronow et al.; Russ et al.). Epigenetic factors associated with drug consumption include a disorder in placental cell secretary function among human chorionic gonadotropin (HCG) hormone secretion. As a result, estrogen and progesterone balance disrupts and then perils embryonic permanence and genesis (Avila et al., 2010; Gluckman \& Hanson). Some epigenetic changes such as DNA methylation changes and 
histone alterations that occur in the genome, are important mechanisms associated with opiate addiction (Esteller \& Herman; Feng \& Nestler, 2013). In addition, molecular and behavioral experiments certify that epigenetic changes have a role in abuse of different drugs such as cocaine, amphetamine, and alcohol (Feng \& Nestler; Fowden et al., 2006). Some epigenetic factors like nourishing and suitable qualifications of pregnancy are efficacious in cytotrophoblastic cells differentiation within the placenta but epigenetic pharmaceutical factors cause changes in genome epigenetic and normal genesis of placental cells (Chelbi \& Vaiman; Feng $\&$ Nestler). Edible morphine used by pregnant mothers increases cytotrophoblastic cells and decreases syncytiotrophoblastic cells. Drugs passing into the placenta are influenced by numerous factors.

Fat soluble compounds pass from placenta easily but water soluble substances pass poorly because of a heavier molecular weight. Drug incorporation with plasma proteins affect the free drug content that can pass into the placenta. Indeed, all drugs except organic ions such as heparin and insulin can pass into the placenta to some degree (Behravan \& Piquette-Miller; Fowden et al., 2006). Because morphine has a small molecular size and is lipophilic, it can easily pass from the placental barrier and cause a delay in placental cell genesis (Behravan \& Piquette-Miller; Kazemi et al., 2010a, 2010b). DNA methylation changes in the placenta depend on the dose of drug consumed. In addition, DNA methylation changes in the placenta are related to opiate use. The main changes occur in CPG islands, whereby one methyl group from a SAM donor adds to C5 of cytosine, so that edible morphine consumption completely depends on the utilization duration (Carter \& Enders, 2004; Williams et al., 2001). Placental cytotrophoblastic and syncytiotrophoblastic cell genesis, and deficiency of placenta creation occur in the 14th day of pregnancy in mothers whom have consumed opiates (Dehghani et al., 2013) (Fig. 1).

Changes that result from morphine consumption as an epigenetic factor on rat placental villi and blood lacuna genesis.

In pregnancy, with more penetration of the trophoblastic pole to deeper parts of endometer, some bubbles appear in cytotrophoblastic cells. When these bubbles associate together, it creates lacuna. Furthermore, trophoblastic cell penetration impairs the capillary endothelial layer and fills cavities with cytotrophoblastic cells, and in this way, blood lacuna form (Carter \& Enders; Russ, et al.). In regards to this point, trophoblastic cells are blood intermediaries between mother and embryo, having an important role in interchanges and are under effect of epigenetic factors. Epigenetic changes that occur in gene expression of trophoblastic cells can cause vessel constriction and embryonic hypoxia (James et al.; Morgan et al., 2005). Faultless development of cytotrophoblast cells guarantees normal genesis of blood lacunas, and if development of these cells are not affected by malformed epigenetic factors, this phenomenon is possible. Intact blood lacunas are suitable milieu for nutrient interchange between mother and embryo

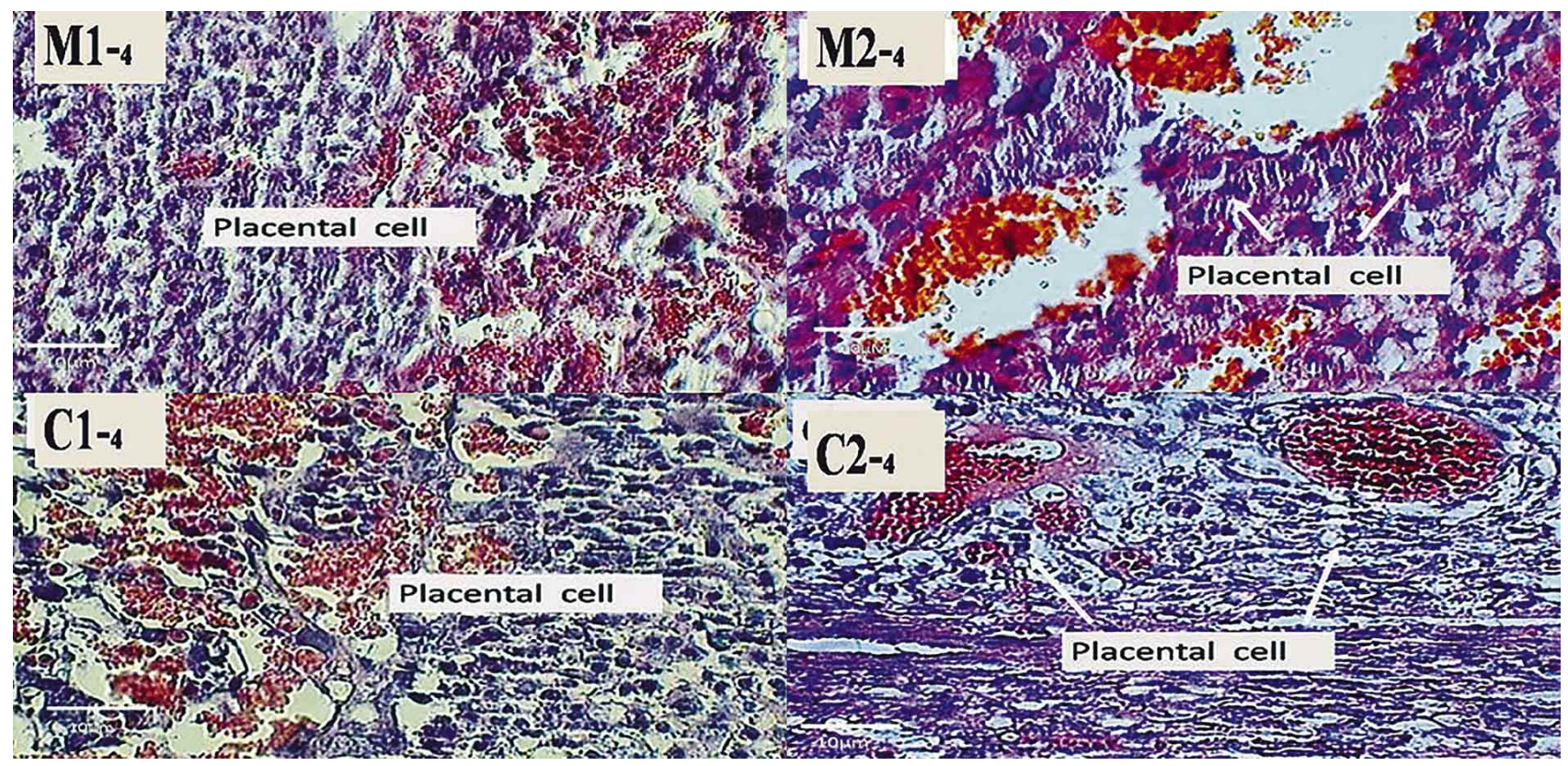

Fig. 1. Microscopic image comparison of changes that result from edible morphine utilization on placental cells in pregnant mothers. On the $10^{\text {th }}$ day of pregnancy (morphine group $\mathrm{M}^{-4}$ and control group $\mathrm{C}^{-4}$ ) (Dehghani et al., 2013) and $14^{\text {th }}$ day of pregnancy (morphine group M2 $2^{-4}$ and control group $\mathrm{C}^{-4}$ ) (Dehghani et al., 2013). 
(Fowden et al., 2006; Kazemi et al., 2010a; Kazemi et al., 2012a, 2012b; Morgan et al.). Drugs are one of the important factors that create main epigenetic changes (DNA methylation and histone alternations). These changes cause disruptions in blood interchanges between mother and embryo as well as with passage from placenta, disrupting embryonic development (Feng \& Nestler; Fowden et al., 2008; Reik). Opioid receptors such as mu, kappa, and delta are affected by edible morphine consumption, and these receptors inhibit AC enzyme via intracellular mechanisms. In this manner, these changes cause a decrease in cAMP and calcium ion entrance and disrupt the normal process of blood lacuna genesis (Nettleton et al.; Seward et al.). Morphine utilization by pregnant mothers causes a decrease in the surface and number of placental blood lacuna. Again, malformed placenta causes intra-uterus growth retardation of the embryo (Dehghani et al.; Kazemi et al., 2010a). The cytotrophoblast is covered by a syncytial layer. In a normal situation of growth and development, mesodermal cells penetrate the primary villi axis and growth toward decidua. In this way, secondary villi will form. The secondary villi axis differentiates to blood vessels and forms third or continual villi (Aronow et al.; Carter \& Enders; Russ et al.). With regard to the high density of mu receptors on the erythrocyte endothelial membrane and maximum accumulation of radioactive morphine absorption in this site, edible morphine consumption by pregnant mothers causes a delay in the developmental stages of blood lacuna. Again, the number and surface of blood lacuna decreases (Dehghani et al.; Kazemi et al., 2012a, 2012b). Defects in third villi genesis cause a deficiency in blood interchanges between mother and embryo, and this result can cause embryonic hypoxia (Adelman et al., 2000; Kazemi et al., 2012a, 2012b) (Fig. 2).

Changes that result from morphine utilization as an epigenetic factor on the development of maternal and embryonic tissues in the rat placenta.

Epigenetic changes that occur from opioid usage such as morphine cause a delay in the genesis of maternal and embryonic tissues of the placenta. Normally, with pregnancy progress, placenta differentiates into two parts. One part is chorionfrondosum, responsible for the greater part of nutrient interchange between mother and embryo. Therefore, malformations that relate to this part are irreparable (Kazemi et al., 2010a; Novakovic \& Saffery). Suitable nutrition is an effective epigenetic factor in the normal genesis of embryonic and maternal tissues of the placenta. On the contrary, opiates are one of the malformed agents that cause epigenetic changes (Morgan et al.; Novakovic \& Saffery). Morphine utilization by pregnant mothers causes a delay in placental tissue genesis especially embryonic tissue of the placenta. Addiction to cocaine and amphetamines leads mostly to acetylation in $\mathrm{H} 3$ and $\mathrm{H} 4$ histones (Feng \& Nestler; Klose \& Zhang, 2007; Williams et al.). Histone alterations are mostly acetylation and phosphorylation that activates transcription on the lysine, serine, threonine, and tyrosine $\mathrm{N}-\mathrm{T}$ tails. After extended treatment with morphine, suppression of mu opioid receptor miRNA expression is one of the morphine tolerance mechanisms (Feng \& Nestler; Klose \& Zhang). Special agonists of mu opioid receptors

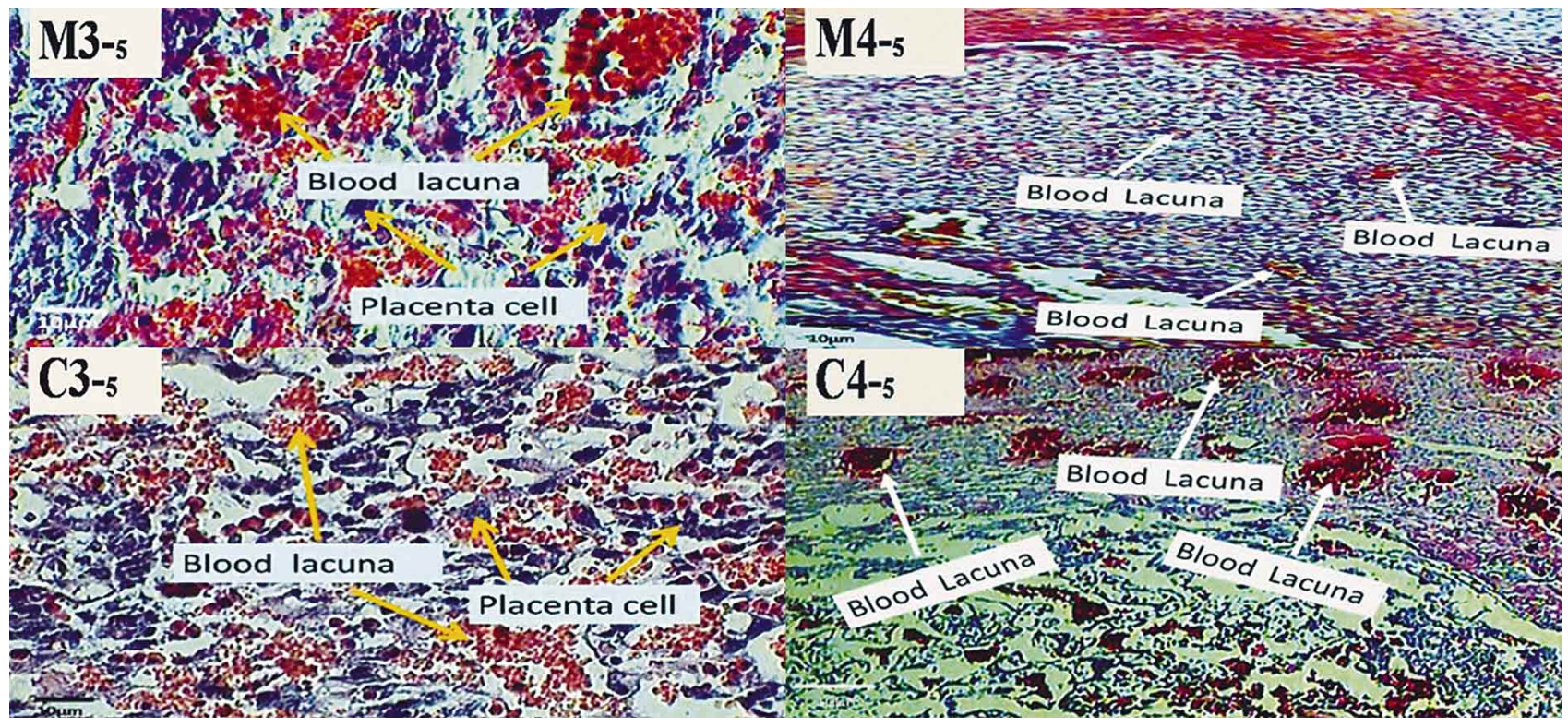

Fig. 2. Microscopic image comparison of changes that result from edible morphine utilization on blood lacuna placental cells in pregnant mothers. On the $10^{\text {th }}$ day of pregnancy (morphine group $\mathrm{M}^{-5}$ and control group C $3^{-5}$ ) (Kazemi et al., 2011b) and $14^{\text {th }}$ day of pregnancy (morphine group $\mathrm{M}^{-5}$ and control group $\mathrm{C}^{-5}$ ) (Kazemi et al., 2012a). 
are efficacious in miRNA expression alteration. Another study using radioactive morphine showed that the placenta of morphine dependent pregnant mothers leads to a defective barrier for the embryo in the primary stages of development, and is strongly affected by morphine. The embryonic portion of the placenta is severely affected by drugs, so that the density of drug absorption is significant. We can conclude that opioid receptors such as mu have more accumulation in the endothelial membrane of the embryonic portion of the placenta; therefore, malformed effects of morphine are more obvious (He et al., 2010; Kazemi et al., 2012a, 2012b; Williams et al.) (Fig. 3). In regards to this point that the embryonic portion has most blood vessels and maximum nutrient interchanges between mother and embryo, epigenetic changes that result from morphine consumption are irreparable. The maternal part of placenta that forms the main deciduous disk is inclined to endometer and is less exposed to damage compared to the embryonic part. However, the maternal part of the placenta has more cytotrophoblast cells that divide and move to the embryonic part of the placenta (Fig. 4). Morphine utilization by pregnant mothers slows the cytotrophoblast cell division; this is a deficiency in normal placental genesis (Fowden \& Forhead; Khalili et al., 2001; Maccani \& Marsit; Reik et al., 2001).

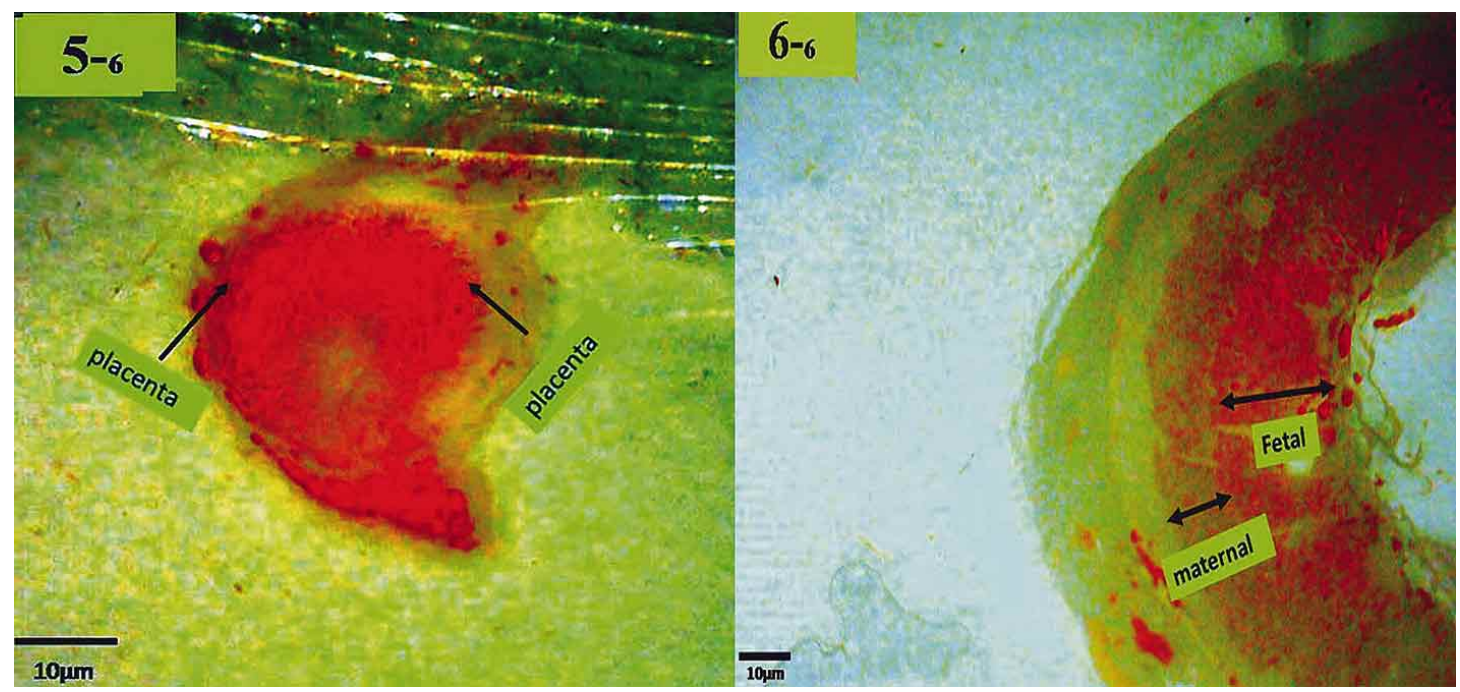

Fig. 3. Picture showing the maximum density of morphine effect on the placenta on the $9^{\text {th }}$ day of pregnancy $\left(5^{-6}\right)$ and on the embryonic part of the placenta on the $14^{\text {th }}$ day of pregnancy $\left(6^{-6}\right)$ in morphine dependent mothers by using radioactive morphine (Kazemi et al., 2012a).

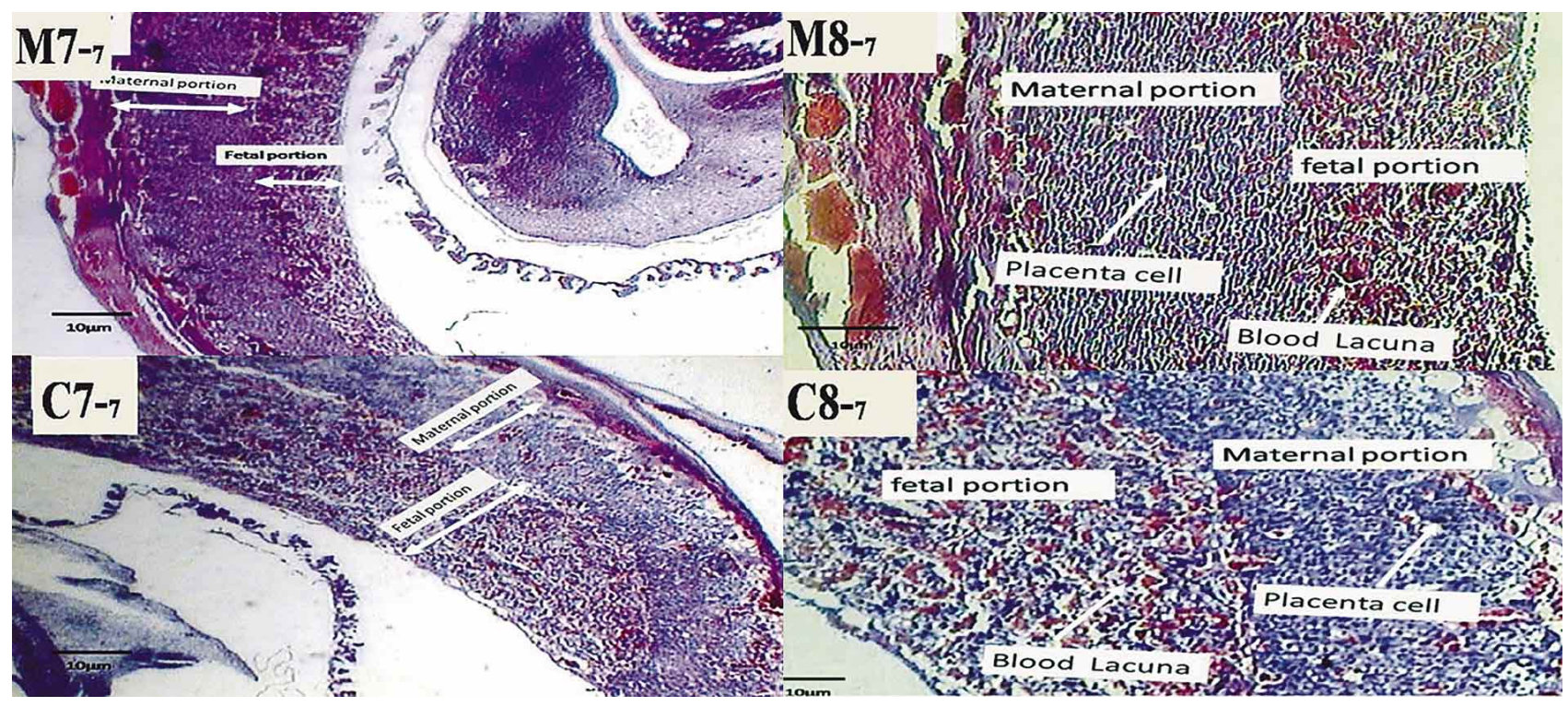

Fig. 4. Microscopic image comparison between changes that result from edible morphine utilization on placental cells of maternal and embryonic parts in pregnant mothers. On the $14^{\text {th }}$ day of pregnancy (morphine group $\mathrm{M}^{-7}$ and control group $\mathrm{C}^{-7}$ ) (Kazemi et al., 2011b) and the $14^{\text {th }}$ day of pregnancy (morphine group $\mathrm{M}^{-7}$ and control group $\mathrm{C}^{-7}$ ) (Kazemi et al., 2011b). 
Morphine consumption, corticosterone concentration and resulting changes in placental genesis in the pregnant rat.

The placenta is a main source of embryo nutrient preparation. On the other hand, the placenta is the main source of hormones necessary for placental growth and genesis (such as estrogen, progesterone and other in demand hormones), especially in the second half of pregnancy (Fowden et al., 2006, 2008). In stress and critical situations, glucocorticoids are secreted in the body. These hormones reinforce the body against stressors. In rat, corticosterone is the effective hormone of glucocorticoids (Fowden \& Forhead; Godfrey). With pregnancy progression, corticosterone rises in the mother's plasma. Stressors are one of the daily epigenetic factors that cause epigenetic changes. In stressful rats (paten from mother), glucocorticoid receptor expression is decreased and responses to stress are increased. Effective epigenetic changes in glucocorticoid receptors are mostly DNA methylation, and in a few cases, histone acetylation. Corticosterone causes proliferation of low differentiation cytotrophoblast cells by shortening the interphase stage; the cell doesn't have enough time for normal growth and genesis. As a result, the cell's function is disrupted (McGowan et al., 2009; Reik; Wilkinson et al., 2009). The approval of edible morphine in pregnant mothers causes a multiplied increase in corticosterone concentration of mothers. This epigenetic factor can affect epigenetic changes in intensity and process, especially DNA methylation (Jaenisch \& Bird, 2003; Kazemi et al., 2011a, 2011b). Morphine andcorticosterone reinforce the function of the other, and cytotrophoblast cells proliferate via shortening of the interphase stage. Moreover, major proliferation of cytotrophoblast cells relevant to maternal part of placenta occurs (Kazemi et al., 2011b; Reik et al.). Increases in corticosterone concentration that result from morphine administration and epigenetic changes are fortified in placental cells, causing a defect in glucocorticoid receptor expression and as a result causes a deficiency in secretory function of placental cells. Studies revealed that the effects of morphine and increases in corticosterone concentration of pregnant mothers cause an increase in the numbers of maternal placental cells. In addition, the thickness of this part in morphine consumers show a significant increase compared with control groups. Nevertheless, cell numbers and thickness of the placental part decrease. Cooperation and reinforcement between morphine and corticosterone function can lead to this changes (Dehghani et al.; Kazemi et al., 2011a, 2011b, 2012a). In some changes due to epigenetic factors, with deduction or complete elimination of the factor, we can eliminate or adjust resultant malformation so that these changes have a direct relation with the duration of exposure to epigenetic factors.
Malformations that result from addiction are affected by epigenetic factors such as malnutrition and opiate consumption. By amendment of nutrition or decrease or elimination of opiate consumption, the resultant changes will be reparable (Bourque et al., 2011; Fowden et al., 2006; Grati et al.). Opiate consumption causes placental villi condensation as well as changes in placental morphology. Addiction is one of most important epigenetic factors in mammals that these changes will be achieved by glucocorticoids assistance (Collins et al., 2005; Delaval \& Feil; Kazemi et al., 2011b). Because we don't know whether the source of the increase in corticosterone concentration in plasma is due to the mother's adrenal cortex, the embryo's adrenal cortex, or placenta secretion directly, corticosterone concentration of plasma is a point that needs further investigation.

\section{CONCLUSION}

Epigenesis is the study of molecular mechanisms that influence how the environment controls the gene's activity. Some factors such as nutrition, drugs, stress, and emotions can change gene expression. Epigenetic factors can turn on or off genes. Morphine is an epigenetic factor that causes epigenetic changes in placenta of mothers that consume opiates. The main epigenetic changes are relevant to DNA methylation and, less so, histone alterations. These changes cause a disruption in the normal genesis of the placenta. Dependency to morphine in pregnant mothers and changes that result from consumption on the placenta can cause embryonic defects in infants of dependent mothers. Recognition of the various kinds of epigenetic factors can adjust or strengthen the resultant epigenetic changes. Acquaintance with these factors is an important before treatments.

\section{ACKNOWLEDGEMENTS}

From Sultan Ali Aliyari and Hamed Aliyari behalf performed extensive research, prepared the manuscript and provide Services.

KAZEMI, M.; TEKIEH, E.; GOLABI, S. \& SAHRAEI, H. Evaluacion de cambios epigeneticos de la placenta por consumo de morfina. Int. J. Morphol., 34(1):252-261, 2016.

RESUMEN: Basado en estudios anteriores, una variedad de elementos bioambientales incluyendo la nutrición inadecuada, 
enfermedades, infecciones, factores de estrés, y los medicamentos están involucrados en los cambios epigenéticos. El abuso de drogas es una de las causas más importantes de los cambios epigenéticos y una preocupación en el mundo actual. Los estudios han demostrado que el uso de la morfina por parte de las madres embarazadas es la causa de varios trastornos en las madres, además de la transferencia de anormalidades a la siguiente generación (la placenta y el embrión). Factores epigenéticos como la morfina causan cambios en la expresión génica en la placenta como la primera barrera de defensa embrionaria. Debido a que la placenta es el medio de todos los intercambios nutricionales entre la madre y la sangre del embrión, la salud de la placenta garantiza el desarrollo embrionario normal. Muchos estudios se han realizado sobre los defectos causados por factores epigenéticos que incluyen el uso de medicamentos. El abuso de opioides, incluyendo la morfina ha puesto en peligro la salud de muchas personas. La morfina produce cambios de expresión génica mediante la unión a los receptores opioides en vellosidades placentarias. Basado en los estudios, los principales cambios epigenéticos debido al consumo de drogas están mediadas por metilación del ADN y los cambios en las histonas. En la actualidad se han publicado estudios referente al conocimiento de diferentes factores epigenéticos y su efecto sobre la placenta y el desarrollo embrionario. La importancia de reconocer los cambios epigenéticos causados por el abuso de drogas por mujeres embarazadas puede ser la forma más importante para prevenir las enfermedades de la edad adulta en el embrión y en algunos casos del aborto espontáneo. Los cambios inducidos por factores epigenéticos pueden ser moderados o revertidos mediante el control de los factores epigenéticos. Este estudio es una revisión de los cambios en el desarrollo de la placenta causados por el uso de morfina en ratas preñadas.

PALABRAS CLAVE: Desarrollo; Morfina; Embrión; Epigenético; Embarazo; Placenta.

\section{REFERENCES}

Adelman, D. M.; Gertsenstein, M.; Nagy, A.; Simon, M. C. \& Maltepe, E. Placental cell fates are regulated in vivo by HIFmediated hypoxia responses. Genes Dev., 14(24):3191-203, 2000 .

Amiel, A.; Bouaron, N.; Kidron, D.; Sharony, R.; Gaber, E. \& Fejgin, M. D. CGH in the detection of confined placental mosaicism (CPM) in placentas of abnormal pregnancies. Prenat. Diagn., 22(9):752-8, 2002.

Aronow, B. J.; Richardson, B. D. \& Handwerger, S. Microarray analysis of trophoblast differentiation: gene expression reprogramming in key gene function categories. Physiol. Genomics, 6(2):105-16, 2001.

Avila, L.; Yuen, R. K.; Diego-Alvarez, D.; Peñaherrera, M. S.; Jiang, R. \& Robinson, W. P. Evaluating DNA methylation and gene expression variability in the human term placenta. Placenta, 31(12):1070-7, 2010
Behravan, J. \& Piquette-Miller, M. Drug transport across the placenta, role of the ABC drug efflux transporters. Expert Opin. Drug Metab. Toxicol., 3(6):819-30, 2007.

Bourque, D. K.; Peñaherrera, M. S.; Yuen, R. K.; Van Allen, M. I.; McFadden, D. E. \& Robinson, W. P. The utility of quantitative methylation assays at imprinted genes for the diagnosis of fetal and placental disorders. Clin. Genet., 79(2):169-75, 2011.

Carter, A. M. \& Enders, A. C. Comparative aspects of trophoblast development and placentation. Reprod. Biol. Endocrinol., 2:46, 2004.

Cedar, H. \& Bergman, Y. Linking DNA methylation and histone modification: patterns and paradigms. Nat. Rev. Genet., 10(5):295-304, 2009.

Chelbi, S. T. \& Vaiman, D. Genetic and epigenetic factors contribute to the onset of preeclampsia. Mol. Cell. Endocrinol., 282(12):120-9, 2008.

Collins, L. R.; Hall, R. W.; Dajani, N. K.; Wendel, P. J.; Lowery, C. L. \& Kay, H. H. Prolonged morphine exposure in utero causes fetal and placental vasoconstriction: a case report. J. Matern. Fetal Neonatal Med., 17(6):417-21, 2005.

Corpening, J. W.; Doerr, J. C. \& Kristal, M. B. Ingested bovine amniotic fluid enhances morphine antinociception in rats. Physiol. Behav., 70(1-2):15-8, 2000.

Cui, M.; Cruz-Correa, M.; Giardiello, F. M.; Hutcheon, D. F.; Kafonek, D. R.; Brandenburg, S.; Wu, Y.; He, X.; Powe, N. R. $\&$ Feinberg, A. P. Loss of IGF2 imprinting: a potential marker of colorectal cancer risk. Science, 299(5613):1753-5, 2003.

DeChiara, T. M.; Robertson, E. J. \& Efstratiadis, A. Parental imprinting of the mouse insulin-like growth factor II gene. Cell, 64(4):849-59, 1991.

Dehghani, L.; Sahraei, H.; Meamar, R. \& Kazemi, M. Timedependent effect of oral morphine consumption on the development of cytotrophoblast and syncytiotrophoblast cells of the placental layers during the three different periods of pregnancy in Wistar rats. Clin. Dev. Immunol., 2013:974205, 2013.

Delaval, K. \& Feil, R. Epigenetic regulation of mammalian genomic imprinting. Curr. Opin. Genet. Dev., 14(2):188-95, 2004.

DiPirro, J. M. \& Kristal, M. B. Placenta ingestion by rats enhances delta- and kappa-opioid antinociception, but suppresses muopioid antinociception. Brain Res., 1014(1-2):22-33, 2004.

Esteller, M. \& Herman, J. G. Cancer as an epigenetic disease: DNA methylation and chromatin alterations in human tumours. $J$. Pathol., 196(1):1-7, 2002.

Feng, J. \& Nestler, E. J. Epigenetic mechanisms of drug addiction. Curr. Opin. Neurobiol., 23(4):521-8, 2013. 
Fowden, A. L. \& Forhead, A. J. Endocrine mechanisms of intrauterine programming. Reproduction, 127(5):515-26, 2004.

Fowden, A. L.; Ward, J. W.; Wooding, F. P.; Forhead, A. J. \& Constancia, M. Programming placental nutrient transport capacity. J. Physiol., 572(Pt. 1):5-15, 2006.

Fowden, A.; Forhead, A. J.; Coan, P. M. \& Burton, G. J. The placenta and intrauterine programming. J. Neuroendocrinol., 20(4):43950,2008 .

Gluckman, P. D. \& Hanson, M. A. Living with the past: evolution, development, and patterns of disease. Science, 305(5691):17336, 2000 .

Gluckman, P. D.; Hanson, M. A.; Cooper, C. \& Thornburg, K. A. Effect of in utero and early-life conditions on adult health and disease. N. Engl. J. Med., 359(1):61-73, 2008.

Godfrey, K. M. The role of the placenta in fetal programming-a review. Placenta, 23(Suppl. A):S20-7, 2002.

Godfrey, K. M.; Lillycrop, K. A.; Burdge, G. C.; Gluckman, P. D. \& Hanson, M. A. Epigenetic mechanisms and the mismatch concept of the developmental origins of health and disease. Pediatr. Res., 61(5 Pt. 2):5R-10R, 2007.

Goswami, D.; Tannetta, D. S.; Magee, L. A.; Fuchisawa, A.; Redman, C. W.; Sargent, I. L. \& von Dadelszen, P. Excess syncytiotrophoblast microparticle shedding is a feature of earlyonset pre-eclampsia, but not normotensive intrauterine growth restriction. Placenta, 27(1):56-61, 2006.

Grati, F. R.; Miozzo, M.; Cassani, B.; Rossella, F.; Antonazzo, P.; Gentilin, B.; Sirchia, S. M.; Mori, L.; Rigano, S.; Bulfamante, G.; Cetin, I. \& Simoni, G. Fetal and placental chromosomal mosaicism revealed by QF-PCR in severe IUGR pregnancies. Placenta, 26(1):10-8, 2005.

Grayson, D. R.; Jia, X.; Chen, Y.; Sharma, R. P.; Mitchell, C. P.; Guidotti, A. \& Costa, E. Reelin promoter hypermethylation in schizophrenia. Proc. Natl. Acad. Sci. U. S. A., 102(26):93416, 2005.

Hajkova, P.; Erdhardt, S.; Lane, N.; Haaf, T.; El-Maarri, O.; Reik, W.; Walter, J. \& Surani, M. A. Epigenetic reprogramming in mouse primordial germ cells. Mech. Dev., 117(1-2):15-23, 2002.

He, Y.; Yang, C.; Kirkmire, C. M. \& Wang, Z. J. Regulation of opioid tolerance by let-7 family microRNA targeting the mu opioid receptor. J. Neurosci., 30(30):10251-8, 2010.

Jaenisch, R. \& Bird, A. Epigenetic regulation of gene expression: how the genome integrates intrinsic and environmental signals. Nat. Genet., 33 (Suppl.):245-54, 2003.

James, J. L.; Stone, P. R. \& Chamley, L. W. The regulation of trophoblast differentiation by oxygen in the first trimester of pregnancy. Hum. Reprod. Update, 12(2):137-44, 2006.

Kazemi, M.; Sahraei, H.; Azarnia, M.; Bahadoran, H. \& Salehy, M. Effect of oral morphine consumption on lacunas development in ten day placenta pregnant Wistar rats. J. Zanjan Univ. Med. Sci., 18(73):26-36, 2010a.

Kazemi, M.; Sahraei, H.; Azarnia, M. \& Bahadoran, H. Effect of oral morphine consumption on maternal and fetal portion placenta cells development in Wistar rat. J. Ardebil Univ. Med. Sci., 10(2):145-54, 2010b.

Kazemi, M.; Sahraei, H.; Azarnia, M.; Dehghani, L. \& Bahadoran, H. Effect of oral morphine consumption in female rats on development of brain cavities, central canal and choroid plexus of their embryos. Cell J., 12(4):489-94, 2011a.

Kazemi, M.; Sahraei, H.; Azarnia, M.; Dehghani, L.; Bahadoran, H. \& Tekieh, E. The effect of morphine consumption on plasma corticosteron concentration and placenta development in pregnant rats. Iran. J. Reprod. Med., 9(2):71-6, 2011 b.

Kazemi, M.; Sahraei, H. \& Dehghani, L. Identification of site of morphine action in pregnant wistar rat placenta tissue: a c(14)morphine study. Cell J., 14(2):122-9, 2012a.

Kazemi, M.; Tekieh, E.; Sadeghi-Gharachdaghi, S.; Ghoshoni, H.; Zardooz, H.; Sahraei, H.; Rostamkhani, F. \& Bahadoran, H. Oral morphine consumption reduces lens development in rat embryos. Basic Clin. Neurosci., 3(3):16-23, 2012 b.

Khalili, M.; Semnanian, S. \& Fathollahi, Y. Caffeine increases paragigantocellularis neuronal firing rate and induces withdrawal signs in morphine-dependent rats. Eur. J. Pharmacol., 412(3):239-45, 2001.

Klose, R. J. \& Zhang, Y. Regulation of histone methylation by demethylimination and demethylation. Nat. Rev. Mol. Cell Biol., 8(4):307-18, 2007.

Li, B.; Carey, M. \& Workman, J. L. The role of chromatin during transcription. Cell, 128(4):707-19, 2007.

Maccani, M. A. \& Marsit, C. J. Epigenetics in the placenta. Am. J. Reprod. Immunol., 62(2):78-89, 2009.

Maltepe, E.; Krampitz, G. W.; Okazaki, K. M.; Red-Horse, K.; Mak, W.; Simon, M. C. \& Fisher, S. J. Hypoxia-inducible factor-dependent histone deacetylase activity determines stem cell fate in the placenta. Development, 132(15):3393-403, 2005.

Maltepe, E.; Bakardjiev, A. I. \& Fisher, S. J. The placenta: transcriptional, epigenetic, and physiological integration during development. J. Clin. Invest., 120(4):1016-25, 2010.

McDonald, J. \& Lambert, D. G. Opioid receptors. Contin. Educ. Anaesth. Crit. Care Pain, 5(1):22-5, 2005. 
McGowan, P. O.; Sasaki, A.; D'Alessio, A. C.; Dymov, S.; Labonté, B.; Szyf, M.; Turecki, G. \& Meaney, M. J. Epigenetic regulation of the glucocorticoid receptor in human brain associates with childhood abuse. Nat. Neurosci., 12(3):342-8, 2009.

Morgan, H. D.; Santos, F.; Green, K.; Dean, W. \& Reik, W. Epigenetic reprogramming in mammals. Hum. Mol. Genet., 14 (Spec. No. 1):R47-58, 2005.

Nettleton, R. T.; Wallisch, M. \& Olsen, G. D. Respiratory effects of chronic in utero methadone or morphine exposure in the neonatal guinea pig. Neurotoxicol. Teratol., 30(5):448-54, 2008.

Novakovic, R. \& Saffery, R. The ever growing complexity of placental epigenetics - role in adverse pregnancy outcomes and fetal programming. Placenta, 33(12):959-70, 2012.

Ornoy, A.; Michailevskaya, V.; Lukashov, I.; Bar-Hamburger, R. $\&$ Harel, S. The developmental outcome of children born to heroin-dependent mothers, raised at home or adopted. Child Abuse Negl., 20(5):385-96, 1996.

Reik, W. Stability and flexibility of epigenetic gene regulation in mammalian development. Nature, 447(7143):425-32, 2007.

Reik, W.; Dean, W. \& Walter, J. Epigenetic reprogramming in mammalian development. Science, 293(5532):1089-93, 2001.

Renthal, W. \& Nestler, E. J. Epigenetic mechanisms in drug addiction. Trends Mol. Med., 14(8):341-50, 2008.

Rozisky, J. R.; Nonose, Y.; Laste, G.; dos Santos, V. S.; de Macedo, I. C.; Battastini, A. M.; Caumo, W. \& Torres, I. L. S. Morphine treatment alters nucleotidase activities in rat blood serum. $J$. Exp. Pharmacol., 4:187-93, 2012.

Russ, A. P.; Wattler, S.; Colledge, W. H.; Aparicio, S. A.; Carlton, M. B.; Pearce, J. J.; Barton, S. C.; Surani, M. A.; Ryan, K.; Nehls, M. C.; Wilson, V. \& Evans, M. J. Eomesodermin is required for mouse trophoblast development and mesoderm formation. Nature, 404(6773):95-9, 2000.

Sahraei, H.; Rostamkhani, F.; Tekieh, E.; Dehghani, L.; Poorazizi, E.; Meamar, R. \& Kazemi, M. Identification of morphine accumulation in the rat embryo central nervous system: a c14morphine administration study. Int. J. Prev. Med., 4(Suppl. 2):S222-8, 2013.

Seward, E.; Hammond, C. \& Henderson, G. Mu-opioid-receptormediated inhibition of the N-type calcium-channel current. Proc. Biol. Sci., 244(1310):129-35, 1991.

Simmons, R. A.; Templeton, L. J. \& Gertz, S. J. Intrauterine growth retardation leads to the development of type 2 diabetes in the rat. Diabetes, 50(10):2279-86, 2001.
Trescot, A. M.; Datta, S.; Lee, M. \& Hansen, H. Opioid pharmacology. Pain Physician, 11(2 Suppl.):S133-53, 2008.

Wilkinson, M. B.; Xiao, G.; Kumar, A.; LaPlant, Q.; Renthal, W.; Sikder, D.; Kodadek, T. J. \& Nestler, E. J. Imipramine treatment and resiliency exhibit similar chromatin regulation in the mouse nucleus accumbens in depression models. J. Neurosci., 29(24):7820-32, 2009.

Williams, J. T.; Christie, M. J. \& Manzoni, O. Cellular and synaptic adaptations mediating opioid dependence. Physiol. Rev., 81(1):299-343, 2001.

\section{Correspondence to:}

Hedayat Sahraei (PhD)

Neuroscience Research Center

Baqiyatallah University of Medical Sciences

Tehran

IRAN

Tel / Fax: (9821)26127286

Email: hsahraei1343@gmail.com

Received: 26-08-2015

Accepted: 18-11-2015 